\section{THE WARBLE-FLY-HYPODERIA.} BY

A. E. SHIPLEY, Sc.D., F.R.S., vaster of christ's college, caMbridge,

"Infinite torment of flies."-Terrysor.

Britain wants many materials in this war, and as long as our back door is open we are getting them. Petrol, rubber, rinc, copper, molybdenum, vanadium, thorium, nickel, saltpetre, wool, cotton, are all coming to us in greaterimneasurably groater-quantities than they can filter through neutral countries into Germany. These things comt. The shortage of leeches in Great Britain on which I have alrearly divelt is neglioible, and is entirely overbalanced by the really serious shortage of sausage-skins in middle Europe. I am told that our meat salesmen at

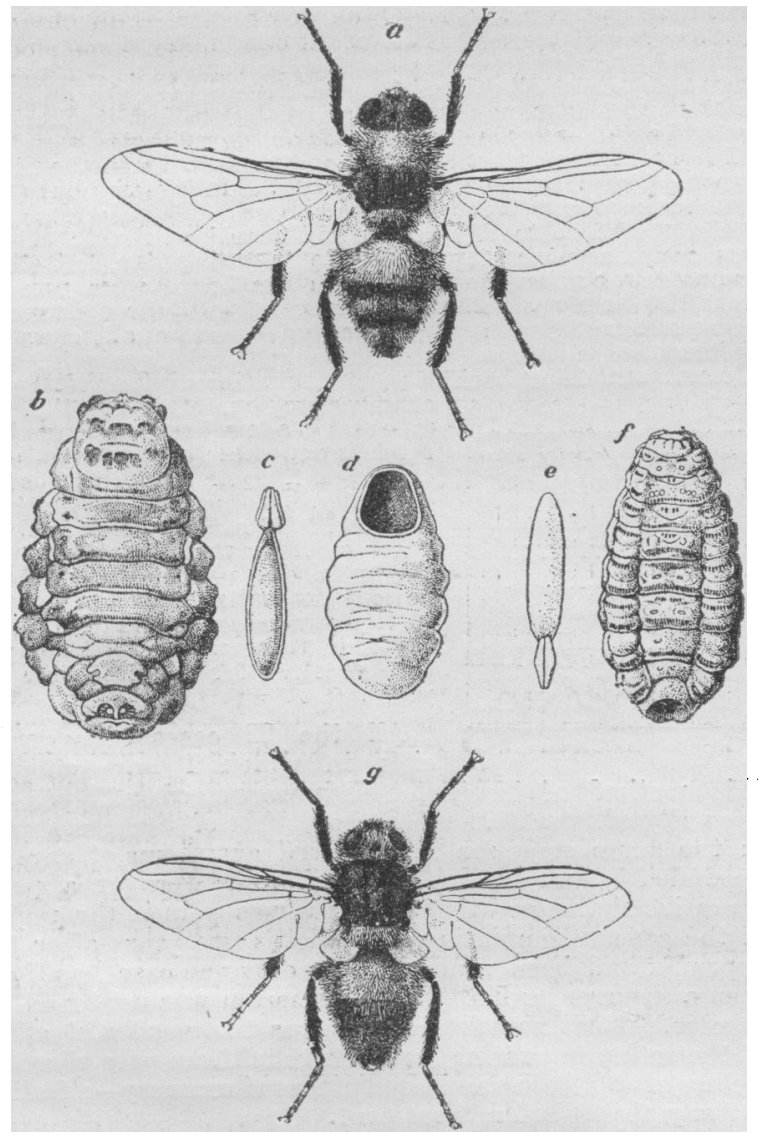

Fig. 1.-a, Hyporerma bovis; $b$, maggot oi $H$. bovis; $c$, egs of H. bovis; d, puparitum of $\boldsymbol{H}$. bovis; $g$, Hypocterma lincata; $e$, egg of $H$ initis.

Smithfield have been offered an incredible advance on the normal rate for these products--so-very-necessary-andunder - no - circumstances - to - be - done - without - with casements-but the neat salesmen at Smithfield are patriots. In their dire extremity the Germans aro trying to make them of cellulose.

Amongst the things both combatants must want is leather. One of the most impressive efforts we noncombatants have becn watching during the last five months is an army growing, near us and next us, with apparently an unlimited supply of leather belts, leather trappings, leather saddlery-leather harness for man and beast. Anything that seriously destroys the continuity of the integunent of our oxen, which interferes with the "wholeness" of the hide which is the basis of leather, clearly affects-and affects detrimentally-an important munition of war. The warble-fly does this; but it does more; its attack materially lessens the value of the beef which potentially lies beneath the hide, and thus in a double sense the warble fly is the enemy of man whether he be soldier or sailor. Further, its attack materially lessens the milk supply of the country.
Amongst the numerous families into which the true flies (Diptera) are divided none are more harmful to human enterprise than that of the OEsTrIDAE, inasmuch as every single species and every single member of this family passes its larval stage within the tissues of some vertebrate host, and most usually in those of domesticated cattle; sometimes even in man himself. One of the com. monest genera of this family of flies is Hypoderma, which is represented in our islands and in many other parts of the world where domesticated cattle are reared by two species, H. bovis and $H$. lineata, both commonly known as Warble-flies.

The harm caused by these larvae, living as they do in the tissues of the body, beneath the skin, by piercing holes through the integument or skin, whereby they make their exit from the "warble" or subcutaneous tumour in which they have passed their latest larval stage, is almost incalculable.

Miss Ormerod, who for so many years kept alight the lamp of economic entomology in England, published some statistics on this subject towards the end of last century. In 1888, out of slightly over 100,000 hides dealt with in the Newcastle cattle and skin market 60,000 were "warbled," and the loss to the trade amounted to $£ 15,000$. The same year at Nottingham 8,500 out of 35,000 hides were largely spoiled; at Manchester 83,500 out of a quarter of a million suffered from the same cause, the losses in these towns being estimated for the year in question at about $£ 2,000$ and $£ 17,000$ respectively. Taking the average from all sources in Englaud, Miss Ormerod estimated the fall in value at from 5s. to 6s. on every warbled hide. The most riddled hides-that is, those with the most punctures-come to the sale-room during April and May, but the trouble extends from February to September.

There is also the loss caused by the warble to the butcher-and through the butcher to the Army Service Corps. The presence of the fly-larva, which is quite a large creature, induces chronic inflammation in the tissues, and a state of things known to the trade as "licked beef," and unless the meat salesman cuts away the affected parts the mcat is unsaleable in the market, or greatly depreciated in value. The average loss to the butcher on a warbled carcass is estimated at $6 \mathrm{~s} .8 \mathrm{~d}$.

Finally there is the loss to the stock raiser and dairy farmer. We shall have occasion later to refer to the curious psychological effect the warble-fly has upon the cattle, causing them to "gad" or stampede in wild gallops, which interferes with fattening, deteriorates the mill supply, and is especially injurious to cows with calf. $\mathrm{M}_{1}$. Imms, in his most useful summary of the warble-fly, tells us that the loss due to $H$. lineata in America is calculated at 28 per cent. of their total value of all the cattle in tho States. Some authorities place the total loss to the agricultural community in England at two, others at seven million pounds a year, whilst others estimate that the loss amounts to about $£ 1$ sterling on every head of horned cattle.

Curiously enough, the fly itself is rarely seen, and still more rarely taken. Mr. Imms records only two specimens of $H$. bovis in the collections of the British Museum, and but fifteen of $H$. lineata. A similar scarcity of imagos in public collections obtains on the other side of the Atlantic, where for many year's the last-named species was alone recognized. Two year's ago, hovever, Dr. Hadwen, working in Canada, established the widespread existence of $H$. bovis in the Dominion; almost certainly it also occurs in the States, but Dr. Hadwen had to send to Dublin for specimens with which to confirm his find. None existed in the collections in Ottawa, and "a request for a specimen . . . from the Bureau of Entomology at Washington, D.C., could not be granted owing to a scarcity of specimens"! These statements are interesting, siuce at present the tanneries of Canada are working night and day to help our shortage in leather at liome.

$H$. bovis measures $\frac{5}{8}$ in. in length, $H$. lineata, somewhat less robust, $\frac{1}{2}$ in.; the colouring of the last named is lighter, white replacing the yellow, and yellow the orangecoloured hairs of $H$. bovis. The flies are most abundant during July and August, thongh they are believed to occui throughout the summer. They fly very rapidly, and are difficult to follow with the eye. They rejoice in war'm, sunny weather, and remain in retirement during cold or cloudy days. Hadwen describes the egg-laying by 
the female "as a sort of frenzied process, the fly striking" with its ovipositor twenty or thirty times rapidly, then leaving the animal for fifteen minutes or so, when the process was repeated. The eggs are attached one at a time to the hairs of the cattle and very close to the base of each hair, not near the tip of each hair, where the horse bot-fly deposits its ova. The favourite region for placing the eggs is on the hock and on the back of the knee, or on the flanks, and hence the American cowboys call the insect, " the heel-fly." Undoubtedly by standing with their legs in water the herd is delivered from the pest, at any rate for the time.

The eggs are large, $1.25 \mathrm{~mm}$. in length, and enclosed in a whitish shell, which is prolonged belind into a brownish foot, and this foot, which exudes some sticky secretion, adheres to the ruminant's hairs. The foot of the ovum, in fact, consists of two lobes or valves, which clasp the hair between their sticky inner surfaces.

Within the egg the youngest of the four larval stages is maturing. Later we find such a stage hatched out and within the tissues of the host, embedded in its muscles and membranes, and now the question confronts us, which once confronted. George III apropos of the apple in the apple dumpling, "How the devil did it get in?" There seen to be with Hypoderma but two modes of entrance into the body of its host, that is, domesticated cattle: (1) The eggs,

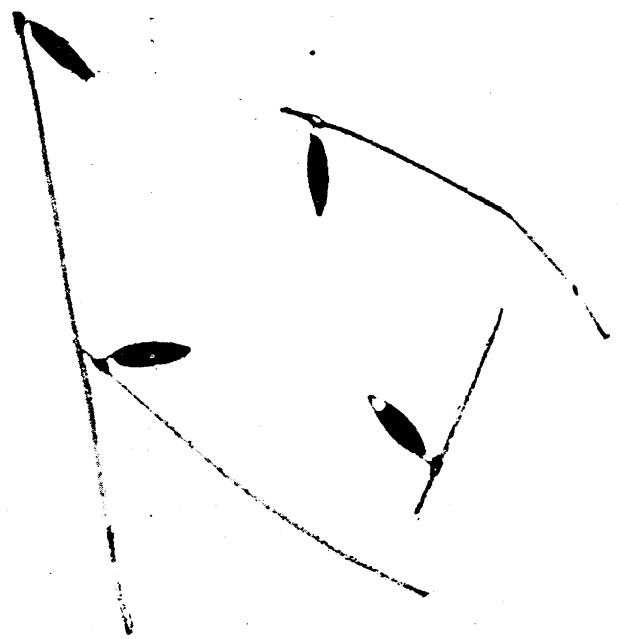
Fig. 2.- Warble-fly eggs attached to hairs. Note attachment
near base. Slightly enlarged.

or the newly-hatched larvae, are licked up by the tongue as are the eggs of the horse bot-fly - and this would explain the not infrequent occurrence of the younger larval stages in the walls of the oesophagus; or (2) the larvae bore their way directly through the skin.

Whatever be their mode of entrance, they seem in their second and their third larval stages to wander frcely through the tissues, especially through the muscular tissues of the body of their host; usually working upwards, and not infrequently reaching the neighbourhood of the vertebral column, before taking up, in the fourth larval stage, their final position in the "warbles," or subcutaneous cysts.

It seems odd that an insect pest, which so seriously affects our supply of leather, of meat and of milk, should have been studied for over a century and yet conceal its chief secret from man. But the problem is much more difficult than the layman thinks. Professor ' 'arpenter and his staff at Dublin have been trying to solve it for some years. After throe years of careful experiment they state, with a good deal of diffidence, that "from experiments," carried on in 1906-7, " with muzzled calves, we conclude that the maggot bores through the skin, and does not enter the beast's body by the mouth." In the next volume of the Journal of the Department of Agriculture for Ireland they state : "The experiment with muzzled calves during 1907-8 seemed indeed to support rather strongly the theory of the maggot's entrance by the mouth ; but those carried on during 1908-9 tend to confirm the results of 1906-7." The following year again they record: "We are forced to conclude that the prevention of licking in the previous muzzling experiments was less perfect than had been supposed, and to admit that these later trials support the view that the maggot (or the egg) may gain entrance to the calf's body by the mouth." We cannot yet regard this important step in the life-history of the warble-fly as definitely settled. It may be that both methods of entrance are used. It is so in the tunnel-or hook-worm (Ankiylostoma duodenale); there the larvae enter both through the skin and by the mouth.

But, whatever. be the mode of entrance, and whatever be the route it travels through the body of the calf or cow, by the spring the fourth larval stage, when it is about an inch long, and perhaps half as much in breadth, is reached in the "warble," or cyst, under the skin. Here, nourished by the products of the inflammation it sets up, and breathing by two spiracles at the hinder end of its body, which are directed to the opening of the "warble". which it has pierced through the skin, the larva rests until one fine night it pushes its way, aided by its stout bristles, through the opening and tumbles into the outer world.

Apparently it does not think much of its new environ ment, for it loses no time in hiding under some clod or stone or crevice in the soil, and straigbtways turns into a dark brown pupa or chrysalis. This stage lasts three to four weeks, and then the perfect fly emerges, and will soon be ready to lay her eggs on some new victim.

As a rule it is the yearlings who suffer most, and then the two-year-olds, the older cattle being comparatively immune. The inexplicable terror which the warble-fly induces in its victims is testified to on all hands, but has never been adequately explained. Hypoderma does noi bite, neither does it sting. Many other blood-sucking insects, whose puncture must involve some pain, are tolerated by cattle. with a flick of the tail, or are frightened off by a gesture of the head, but the presence of the warble-fly induces a mysterious fear which rapidly spreads through a herd, and results in a general stampede, often referred to by cattle breeders as the "gad." This terror communicates itself even to the "stalled ox," and cattle confined within cowsheds show symptoms of extraordinary unrest when the fly is abroad amongst their kin in the pastures. The resulting evils are, of course, far graver in the unlimited prairies of the West-the great cattlebreeding districts of the United States and Canada-than in our carefully hedged or fenced meadows. A great many "dips," ointments, and chemical solutions have been recommended for the prevention of the grubs in cattle, but none have proved really satisfactory. The tedious method of removing the grub from the tumour is the only safe one. This can be done by the mere pressure of the fingers when the grub is nearly mature and ready to leave its host, or by the use of small forceps should the grub be young and recalcitrant. Once removed, the grub should at once be destroyed, and some such antiseptic as coal-tar applied to the vacated tumour.

\section{MEDICAL WORK IN THE EARLY SE'VENTIES} IN A COUNTY INFIRMARY IN ULS'TER.

BY

GEORGE ST. GEORGE, M.R.C.P.I., SURGEON, CO. ANTRIM INFIRMARY, LISBURN; CHATRMAN, BELFAST

Wires one, like myself, has come to be a superveteran, and has trod the via medicalis for almost half a century, one feels that one's feet have become inured to the hills and hollows and the hardships of the road. On looking back on those pre-antiseptic days the first impression is one of sorrow-sorrow for the many failures and for the many lives we now know were lost. That sorrow is, how. ever, tempered by the thought that the work done was good work and that it was the best that could be done in those early days. It is well to remember that we were but the pioneers, doing rough work it is true, but still good work that laid the foundations for medical science as it is to-day.

Like all others of those times who elected to become doctors it was necessary to become apprenticed to some medical man and then learn the rudiments. I was apprenticed to Dr: Thompson of Lisburn, who was then surgeon to the Co. Antrim Infirmary. To attend at his house or

* An address delivered at the winter meeting of the Division. 